\title{
Peran pendidikan Pancasila dalam pembentukan karakter
}

\section{Silvia Oktaviana Lestari, Heri Kurnia}

Prodi PPKn, Universitas Cokroaminoto Yogyakarta, Yogyakarta, Indonesia

\begin{tabular}{|c|c|}
\hline INFORMASI ARTIKEL & ABSTRAK \\
\hline $\begin{array}{l}\text { Sejarah Artikel: } \\
\text { Diterima: 18/01/2022 } \\
\text { Disetujui: 31/01/2022 } \\
\text { Kata kunci: } \\
\text { Pendidikan } \\
\text { Pancasila } \\
\text { Karakter } \\
\text { Keywords : } \\
\text { Education } \\
\text { Pancasila } \\
\text { Character }\end{array}$ & 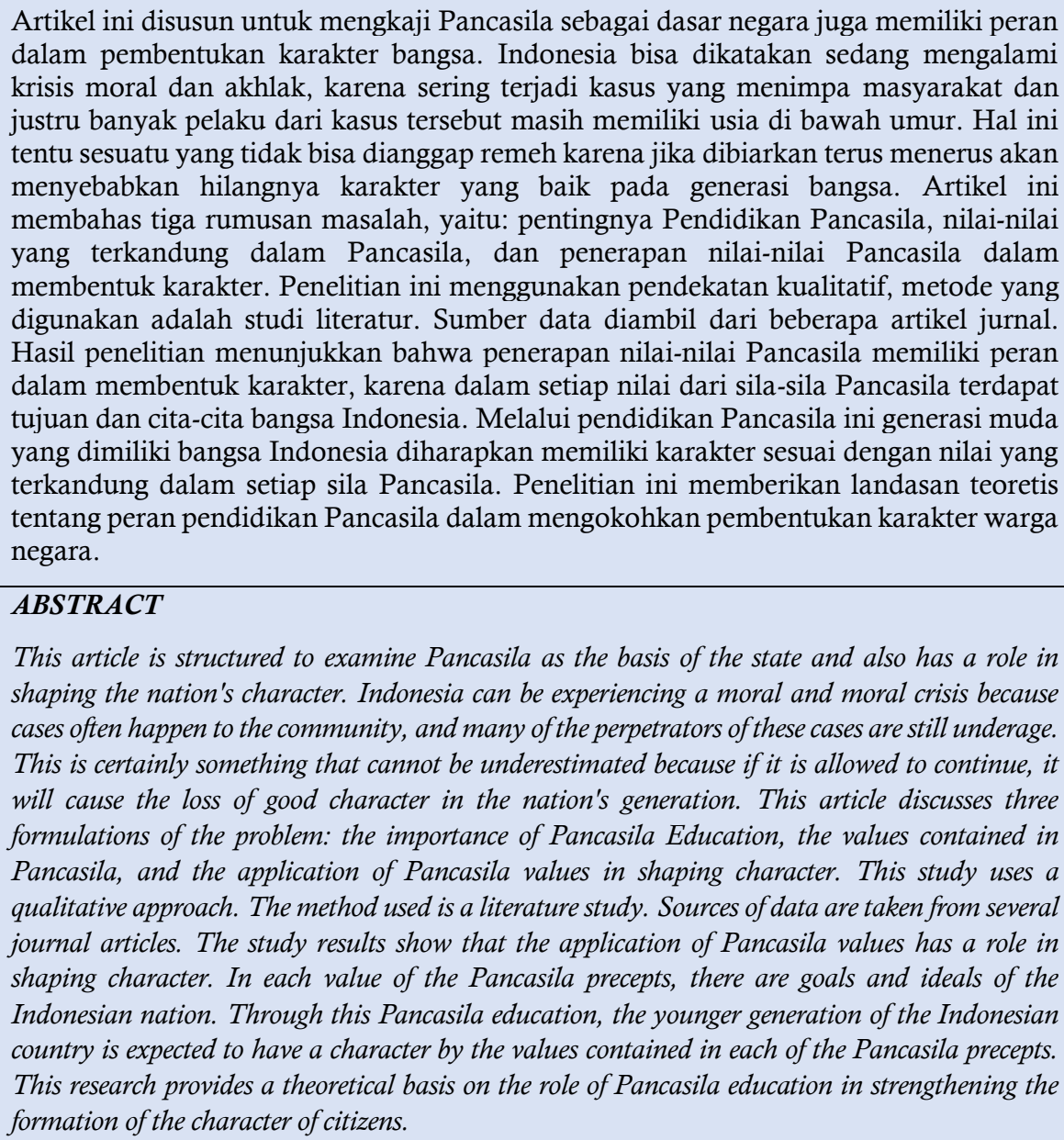 \\
\hline
\end{tabular}

\section{Pendahuluan}

Indonesia merupakan salah satu negara yang terdiri dari beberapa kepulauan tentu hal ini menjadikan Indonesia memiliki banyak ragam suku, ras, adat dan budaya yang ada. Memiliki banyak budaya juga menimbulkan banyak perbedaan, namun hal ini memiliki dampak positif yaitu adalah tumbuhnya sikap toleransi karena adanya perbedaan, namun juga memiliki dampak negatif dimana dapat menjadikan tantangan bagi kita. Keanekaragaman inilah yang harus tetap kita jaga dan jangan sampai menjadi alasan timbulnya perpecahan. Dengan banyaknya pulau dan keanekaragaman inilah tentu Bangsa Indonesia memiliki banyak generasi penerus bangsa yang ada di berbagai daerah. Sudah menjadi kewajiban kita untuk membentuk generasi penerus bangsa tersebut agar memiliki karakter yang dapat mewujudkan cita-cita bangsa Indonesia (Alzanaa \& Harmawati, 2021).

Dengan adanya keberagaman dan dalam banyak nya perbedaan moral menjadi salah satu hal wajib yang harus dimiliki setiap warga negara Indonesia. Menumbuhkan sikap toleransi demi terciptanya kehidupan yang aman dan damai. Moralitas adalah sikap moral, yang dilakukan dengan 
tulus tanpa tujuan hanya ingin dipuji oleh orang lain. Moral merupakan aspek dasar dalam menjalin hubungan baik dengan tuhan, manusia dengan manusia serta kita sebagai makhluk pribadi.

Dalam mewujudkan cita-cita Bangsa Indonesia tentu generasi penerus bangsa harus mendapatkan Pendidikan yang layak agar kelak mereka dapat bersaing dengan generasi penerus bangsa lain. Pendidikan merupakan salah satu cara yang dapat digunakan untuk mendukung pembangunan nasional. Seperti yang telah kita ketahui tercantum dalam pembukaan UndangUndang Dasar 1945 terdapat bunyi "mencerdaskan kehidupan bangsa". Selain itu terdapat pula dalam Pasal 3 Undang-Undang No.20 tahun 2003 dijelaskan bahwa "pendidikan nasional memiliki fungsi untuk membentuk dan mengembangkan kemampuan serta karakter untuk membangun bangsa". Tentu hal ini menjadi salah satu alasan bahwa pendidikan sangat penting dan wajib untuk didapatkan. Hal ini tentu memiliki tujuan untuk membentuk dan mengembangkan potensi generasi penerus bangsa selain memiliki kecerdasan dalam ilmu-ilmu umum namun juga harus menjadi manusia yang bertakwa, memiliki akhlak yang baik, berkarakter yang baik dan menjadi warga negara Indonesia yang memiliki dan menerapkan nilai-nilai demokratis. Selain itu juga harus memiliki jiwa nasionalisme sehingga akan mencintai negaranya dengan sepenuh hati dan menjadi warga negara yang baik dengan menjalankan kehidupan bermasyarakat, berbangsa dan bernegara sesuai dengan nilai-nilai yang tercantum pada Undang-Undang Dasar serta Pancasila yang dijadikan pedoman (Asmaroini, 2016).

Hal ini menjadi bukti bahwa Pendidikan Pancasila sangat dibutuhkan serta memiliki peran untuk memberikan pedoman dimana nilai-nilai yang ada di dalam Pancasila dapat dijadikan dasar dan pedoman untuk pendidikan di Indonesia. Pendidikan Pancasila tentu memiliki fungsi yang dapat membentuk maupun mengubah cara berpikir maupun karakter seseorang karena nilai-nilai yang ada di dalam Pancasila. Dalam hal ini Indonesia saat ini sedang mengalami krisis moral, dimana terdapat banyak generasi muda yang moralnya rusak yang disebabkan oleh berbagai faktor yang dapat mempengaruhi, yaitu baik dari faktor internal maupun dari faktor eksternal. Faktor internal yang dapat mempengaruhi antara lain adalah tidak bisa membedakan dan membatasi mana yang baik dan mana yang buruk, serta tidak bisa mengontrol diri untuk menghindari dari perbuatan yang dapat menjerumuskan kedalam hal-hal negatif. Kemudian faktor eksternal yang mempengaruhi antara lain lingkup pergaulan, penggunaan media sosial yang kurang tepat, narkoba, tawuran dan minuman keras. Keadaan yang tentu sangat memprihatinkan dan harus di tangani dengan serius. Karena kita tahu bahwa mereka adalah generasi penerus bangsa dan merekalah yang akan melanjutkan perjuangan dan mewujudkan cita-cita bangsa Indonesia dengan segala daya dan upayanya. Jika generasi kita memiliki moral yang rusak tentu hal ini akan berpengaruh, sehingga bangsa kita tidak akan bisa bersaing dengan bangsa lain. Untuk itu kita harus memberikan pendidikan yang berkaitan dengan moral dan akhlak sejak dini. Penerapan Pancasila kedalam pembelajaran dalam bentuk Pendidikan Pancasila merupakan hal wajib untuk dilaksanakan karena akan berdampak positif pada karakter generasi penerus bangsa. Hal ini memiliki tujuan untuk membentuk karakter yang baik berdasarkan dengan nilai-nilai yang terkandung dalam setiap butir sila Pancasila (Nurgiansah, 2021).

Pendidikan adalah bagian dari upaya untuk membentuk peserta didik yang memiliki banyak kemampuan baik secara akademis maupun moralitas yang baik, dengan pendidikan maka diharapkan terjadi keseimbangan antara dua aspek tersebut. Peran pendidikan merupakan hal yang penting karena tujuan dari pendidikan sendiri sesuai dengan cita-cita bangsa Indonesia. Setiap orang memiliki hak yang sama untuk mendapatkan pendidikan yang layak. Di dalam lingkungan sekolah sering terjadi permasalahan yang berkaitan dengan nilai, moral, dan tingkah laku. Hal ini bisa menjadi salah satu cara untuk memberikan dan membentuk karakter sejak dini melalui mata pelajaran pendidikan Pancasila, pemahaman mengenai karakter harus dimiliki sejak dini. Dengan pendidikan tentu kita dapat mengubah perilaku seseorang, melalui sebuah tahap pembelajaran. Lingkungan juga dapat mempengaruhi karakter dan tingkah laku seseorang, baik lingkungan sekolah, keluarga dan masyarakat tentu masing-masing memiliki peran dan pengaruh yang besar terhadap karakter. Jika ketiga lingkungan tersebut dapat memberikan pengaruh dan dorongan yang baik maka kita juga akan menjadi baik, selain itu semua juga tergantung pada bagaimana cara kita menyikapi dan membatasi diri dari suatu hal yang dapat menjerumuskan. Memiliki kecerdasan intelektual dan kecerdasan emosional sangat penting untuk dimiliki setiap orang dalam bersikap dan bertingkah laku (Wadu et al., 2019). 
Pendidikan di Indonesia sendiri ada tiga yaitu formal, informal, dam non formal, yang terdiri dari lingkungan sekolah, keluarga dan masyarakat. Dari ketiga jenis pendidikan tersebut dimana pun dan dengan siapa pun kita akan mendapat pendidikan, tinggal bagaimana cara kita menangkap materi dan kemudian menyampaikannya kepada orang lain agar kelak menjadi ilmu yang bermanfaat.

\section{Metode}

Penelitian ini menggunakan pendekatan kualitatif dengan metode studi literatur untuk memperoleh data dan mengetahui bagaimana pendidikan Pancasila memiliki peran dalam pembentukan karakter. Teknik yang digunakan adalah dengan mencari dan mengumpulkan jurnal referensi dan sumber lain kemudian membacanya satu per satu jurnal yang berkaitan dengan judul lalu selanjutnya dipahami dan ditelaah kemudian mencatat poin penting. Data yang telah diperoleh dikaji sehingga dapat dituangkan dalam bentuk bahasa penulis sesuai dengan hasil penelitian yang telah didapat sebelumnya.

\section{Hasil dan Pembahasan}

\section{Pentingnya Pendidikan Pancasila}

Indonesia memiliki banyak ragam kebudayaan baik suku, ras, dan agama tentu hal ini membutuhkan suatu hal yang dapat dijadikan sebagai pedoman agar tidak terjadi perpecahan akibat banyak perbedaan tersebut. Perkembangan arus globalisasi dan pesatnya perkembangan ilmu teknologi tentu dapat menimbulkan berbagai macam masalah dan rintangan yang harus dihadapi karena hal ini tentu memiliki dampak positif namun tentu juga memiliki dampak negatif. Konflik yang dapat mengancam persatuan dan kesatuan Negara Kesatuan Republik Indonesia harus kita hadapi bersama. Semakin cepatnya arus globalisasi juga dapat menimbulkan munculnya paham dan ideologi baru yang bertentangan dengan nilai-nilai Pancasila. Dampak nya yaitu pada penurunan nilai Pancasila. Penguatan mengenai ideologi dan nilai Pancasila harus dilakukan agar tetap memperkuat nilai yang ada dalam setiap butir sila Pancasila (Resmana \& Dewi, 2021).

Pendidikan Pancasila wajib diberikan baik pada masyarakat umum maupun annak usia dini. Masih terdapat banyak orang yang belum bisa menerapkan nilai-nilai Pancasila dalam kehidupannya. Pancasila dapat dijadikan sebagai pemersatu bangsa jika terjadi konflik. Dampak dari globalisasi yang menyebabkan kebudayaan asing masuk pada masyarakat sehingga berakibat pada menurunnya moral bangsa. Banyaknya pengaruh, baik dari internal maupun eksternal tentu dapat mempengaruhi masyarakat, diharapkan Pancasila dapat memperkuat sikap dan sifat dalam menyikapi globalisasi dan perkembbangan tekhnologi (Anggraini et al., 2020).

Dalam kehidupan, Pancasila memiliki kedudukan dan peran yang sangat penting. Tercantum pada ketetapan MPR NO II/MPR/1978, Pancasila diartikan sebagai jiwa yang dimiliki oleh seluruh rakyat Indonesia, dimana di dalamnya terdapat pandangan hidup bangsa, kepribadian serta dasar Negara bagi seluruh rakyat di Indonesia. Dengan demikian tentu harus ada upaya untuk tetap menjaga nila-nilai luhur yang terdapat di dalamnya.

Pancasila sebagai dasar negara tentu dijadikan sebagai dasar dan pedoman dalam hidup berbangsa dan bernegara. Karena didalam Pancasila terdapat tujuan, cita-cita dan harapan yang dimiliki oleh Bangsa Indonesia yang tertulis dalam setiap butir sila nya. Dalam Pendidikan Pancasila ini lah kita dapat belajar dan mengetahui nilai-nilai apa saja yang terdapat pada Pancasila serta bagaimana cara untuk menerapkan nilai-nilai yang tersebut dalam kehidupan bermasyarakat. Pendidikan Pancasila sangatlah penting untuk didapat setiap warga negara Indonesia karena sebagai pondasi dasar dalam membentuk karakter, dimana sekolah menjadi salah satu lingkungan yang tepat sebagai sarana untuk berlangsungnya kegiatan dimana memberikan Pendidikan Pancasila yang diberikan sejak usia dini. Dalam hal ini tentu sekolah memiliki peran dan harus memberikan dorongan kepada peserta didik agar berperilaku dan memiliki karakter sesuai dengan nilai-nilai yang terdapat didalam Pancasila. Pengembangan moral dan karakter peserta didik dilingkungan sekolah menjadi hal yang wajib dilakukan agar terbentuk moral dan karakter peserta didik yang baik, serta menjadi generasi yang sesuai dengan nilai-nilai dan karakter Pancasila (Hanum, 2019).

Pendidikan Pancasila merupakan bagian dari pendidikan kewarganegaraan yang terfokus pada penanaman dan pemberian materi terkait ideologi Pancasila ke dalam materi pembelajaran kemudian 
di berikan kepada peserta didik agar menjadi warga negara yang memiliki karakter baik. Dapat dikatakan Pendidikan Pancasila adalah pendidikan ideologi di Indonesia.

\section{Nilai-nilai yang Terkandung dalam Pancasila}

Pancasila merupakan dasar Negara dimana sila-sila yang terdapat dalam Pancasila merupakan suatu sistem nilai, oleh sebab itu pada dasarnya sila-sila pada Pancasila merupakan satu kesatuan. Nilai-nilai dalam Pancasila juga dapat dikatakan sebagai pandangan hidup bangsa Indonesia karena sesuai dengan cita-cita dan tujuan yang dimiliki bangsa Indonesia. Seperti yang telah disampaikan bahwa nilai Pancasila memiliki fungsi yaitu untuk menjadi landasan, mengarahkan, mengendalikan serta menentukan bagaimana cara berperilaku seseorang untuk berinteraksi antara manusia dengan manusia dalam menjalankan kehidupan bermasyarakat, berbangsa dan bernegara. Pancasila memiliki lima sila dimana setiap butir silanya mengandung maknanya tersendiri yang sesuai dengan kepribadian bangsa Indonesia (Sulianti et al., 2020).

Terdapat pada sila pertama yaitu, Ketuhanan Yang Maha Esa memiliki makna dan arti nilai bahwa sebagai bangsa, kita juga harus melaksankan kodrat sebagai seorang manusia yaitu taat dan patuh terhadap Tuhan. Hal ini menjadi faktor adanya kemerdekaan beragama serta menjalankan kebaikan sesuai dengan ajaran baik setiap Tuhan yang di percayai masing-masing pemeluk agama. Warga negara bebas menganut dan beribadah sesuai dengan kepercayaan yang dianut. Sila kedua yaitu Kemanusiaan yang Adil dan Beradab memiliki makna dan arti nilai bahwa setiap manusia memiliki kedudukan dan hak yang sama. Sebagai seorang manusia tentu harus memiliki adab dalam berpikir, berbicara dan bertindak, dan sebagai warga negara tentu sudah sepantasnya memiliki sikap dan tingkah laku sebagaimana mestinya. Sila ketiga yaitu Persatuan Indonesia memiliki makna dan arti nilai bahwa Indonesia adalah salah satu negara yang terdiri dari beberapa pulau, karena hal inilah Indonesia memiliki ragam suku, ras, agama, golongan dan kebudayaan. Indonesia memiliki semboyan yang ada pada lambang negara tepatnya pada ekor burung garuda yang bertulisankan Bhinneka Tunggal Ika, yang memiliki arti bahwa dalam banyaknya perbedaan yang ada tetapi masih satu kesatuan yaitu bangsa Indonesia. Nilai pada sila ketiga ini harus diterapkan karena akan menimbulkan sikap toleransi. Sila keempat yaitu, Kerakyatan yang Dipimpin oleh Hikmat Kebijaksanaan dalam Permusyawaratan Perwakilan memiliki makna dan arti nilai yang berhubungan dengan demokrasi diantaranya adalah musyawarah secara mufakat dengan mementingkan kepentingan bersama diatas kepentingan individu. Serta mendengar dan menghargai pendapat dari orang lain. Bentuk dari demokrasi yaitu setiap orang memiliki hak yang sama, serta memiliki wewenang penuh atas hak asasi yang dimiliki dan memiliki kebebasan dalam menyampaikan pendapat mengenai berbagai hal. Sila kelima yaitu Keadilan Sosial Bagi Seluruh Rakyat Indonesia memiliki makna dan arti nilai bahwa keadilan sosial merupakan cerminan bangsa Indonesia yang mampu bersiikap adil dengan memberikan hak yang sama dan mendapat perlindungan serta keadilan sebagai seorang warga negara. Nilai yang terkandung pada sila kelima tentu harus di terapkan agar warga negara mendapatkan keadilan yang sama demi mewujudkan kesejahteraan bersama. Setiap butir sila memiliki makna dan arti nilai yang harus ditanamkan diantaranya, nilai agama, nilai sesuai dengan kaidah sosial, nilai toleransi, nilai kemusyawarahan dan nilai keadilan. Hal ini sesuai dengan dasar dan konsep pendidikan karakter menurut Depdiknas yang memiliki 11 nilai karakter diantaranya adalah ketaqwaan, kejujuran, kedisiplinan, demokratis, adil dan beradab, bertanggung jawab, cinta tanah air atau nasionalisme, orientasi pada keunggulan dan potensi yang dimiliki, gotong royong, menghargai antar sesama, dan rela berkorban demi bangsa dan negara. Nilai-nilai inilah yang menjadi alasan bahwa Pancasila memiliki peran dalam membentuk karakter bangsa dengan menjadikannya sebagai pedoman (Adha \& Susanto, 2020).

\section{Pendidikan Karakter}

Dijelaskan juga bahwa karakter yang dimiliki setiap individu yang terdapat pada nilai dari setiap butir sila-sila Pancasila yang terdiri dari dua sumber yaitu karakter yang bersumber dari hati nurani dan dari pola pikir manusia. Karakter yang bersumber dari hati antara lain yaitu jujur, beriman dan bertaqwa, adil, tertib, amanah, taat aturan, bertanggung jawab, berempati, berani mengambil resiko, pantang menyerah, rela berkorban dan berjiwa nasionalisme. Sedangkan untuk karakter yang bersumber dari olah pikir manusia antara lain yaitu cerdas, inovativ, rasa ingin tahu nya tinggi, produktif dan peka terhadap lingkungan sekitar. Sesuai dengan apa yang tercantum dalam UU N0 20 Tahun 2003 tentang Sistem Pendidikan Nasional yang menyatakan bahwa " Pendidikan Nasional 
memiliki fungsi dan tujuan untuk mengembangkan dan membentuk watak serta karakter sesuai peradaban bangsa yang bermartabat dengan tujuan untuk mencerdaskan kehidupan bangsa, serta mengembangkan potensi peserta didik agar kelak memiliki bekal untuk menjadi manusia beriman dan bertakwa kepada Tuhan Yang Maha Esa, berakhlak mulia, berilmu, kreatif, cakap dan tanggap, dan menjadi warga negara yang kritis, demokratis serta bertanggung jawab. Sesuai dengan UndangUndang yang telah disebutkan dapat diketahui bahwa pendidikan karakter merupakan pendidikan yang sangat penting dan dapat dijadikan hal wajiib untuk diberikan sesuai dengan apa yang terdapat pada amanat Pancasila dan Undang-Undang tentang Sitem Pendidikan Nasional. Pengembangan dan pembinaan karakter terhadap manusia terutama generasi muda dapat dijalankan dengan melalui beberapa upaya yaitu termasuk melalui pendidikan yang dilakukan secara struktural dan terprogram, bertahap, dan saling berhubungan. Pendidikan karakter merupakan upaya untuk terciptanya linngkungan sekolah yang dapat membantu siswa dalam mengembangkan etika, tanggung jawab melalui model pembelajran terstruktur, dan pengajaran karakter yang baik melalui nilai-nilai universal (Mustoip et al., 2018).

Menurut salah satu tokoh pendidikan di Indonesia yaitu KI Hajar Dewantara menyampaikan bahwa pendidikan adalah upaya sadar yang dilakukan untuk mengembangkan segala aspek yang dimiliki oelh masing-masing orang yaitu berupa pengetahuan, sikap, keterampilan, dan budi pekerti. Karakter dapat dikatakan sebagai watak, sifat tingkah laku maupun cara bersikap setiap orang. Karakter dari dua sifat yaitu sifat baik dan sifat buruk, baik atau buruknya seseorang dapat kita lihat dari cara seseorang berperilaku. Jika seseorang mampu memiliki sifat baik dan berperilaku dengan baik maka karakter orang itu juga baik begitu juga dengan sebaliknya jika seseorang memiliki sifat yang tidak baik dan berperilaku tidak baik maka berdasarkan hal tersebut dapat dikatakan bahwa orang itu memiliki karakter yang tidak baik, hal ini terjadi karena tingkah laku seseorang dapat mempengaruhi baik buruknya karakter orang tersebut. . Maka wajar jika nilai-nilai karakter yang baik menjadi hal yang wajib diberikan dan diterapkan kepada peserta untuk dijadikan bekal, sehingga kelak mereka mampu menerapkan nilai tersebut dalam menjalani hidup baik di lingkungan keluarga, masyarakat, sekolah, serta bangsa dan negara, sehingga dapat memberikan dampak yang positif kepada lingkungannya. Pendidikan Pancasila juga memiliki tujuan untuk memberikan dan menanamkan nilai positif ke pada setiap peserta didik untuk terbentuknya akhlak yang mulia. Pendidikan karakter memiliki tiga fungsi utama diantaranya adalah: Pertama, fungsi unntuk membentuk membentuk dan pengembangan potens yang dimiliki. Pembentukan karakter membentuk dan mengembangkan potensi peserta didik agar memiliki pola pikir yang baik, berhati mulia, dan berperilaku sesuai dengan filsafah Pancasila. Kedua, fungsi untuk memperbaiki dan penguatan. Pendidikan karakter memperbaiki dan memperkuat hubungan dan peran keluarga, satuan pendidikan, masyarakat dan pemerintah untuk ikut serta berpartisipasi dan bertanggung jawab dalam mengembangan potensi yang dimiliki setiap warga negara dan pembangunan bangsa yang agar lebih maju, mandiri adil dan sejahtera. Ketiga, fungsi penyaring. Pendidikan Karakter dapat digunakan untuk memilah budaya bangsa sendiri dan manyaring budaya bangsa lain yang bertolak belakang dan tidak sesuai dengan nilai-nilai budaya dan karakter bangsa yang bermartabat (Sayektiningsih et al., 2017).

Tujuan Pendidikan Karakter yang diharapkan oleh Kementrian Pendidikan Nasional (sekarang: Kementrian Pendidikan dan Kebudayaan) adalah seperti berikut, yang pertama adalah mengembangkan kemampuan yang terdapat pada hati nurani peserta didik sehingga dapat menjadi pribadi dan warga negara yang memiliki sifat dan karakter sesuai bangsa. Kedua, mengembangkan dan menerapkan sikap dan perilaku sesuai dengan nilai dan kebiasaan bangsa Indonesia sebagai orang yang taat, patuh, serta religius. Ketiga mengembangkan dan menerapkan jiwa sebagai seorang pemimpin serta mengembangkan menerapkan rasa tanggung jawab sebaggai generasi penerus bangsa. Keempat, mengembangkan dan menerapkan kemampuan peserta didik sehingga dapat menjadi manusia mandiri, memiliki kreatifitas, dan memiliki wawasan kebangsaan. Kelima, menjadikan lingkungan sekolah sebagai tempat yang nyaman, sehingga tidak akan membuat bosan ketika berada di lingkungan sekolah (dignity). 


\section{Penerapan Nilai-nilai Pancasila dalam Membentuk Karakter}

Sebagai makhluk individu manusia tentu tidak dapat hidup tanpa bantuan dan campur tangan orang lain. Hal ini tentu menjadi alasan segala sesuatu yang kita lakukan pada dasarnya ada bantuan dari orang lain. Sebagai alasan mengapa sebagai manusia harus selalu berbuat baik pada sesama. Pentingnya pengendalian diri untuk dapat membangun koneksi antar masyarakat sangat dibutuhkan terlebih Indonesia adalah negara yang terdiri dari berbagai macam suku, ras, dan budaya. Sehingga tercipta rasa persatuan dan kesatuan dalam kehidupan bermasyarakat. Menurut pandangan Pancasila hubungan antar individu dengan Pancasila dijiwai oleh nilai-nilai yang terkandung dalam setiap silasila Pancasila sebagai satu kesatuan. Manusia tentu membutuhkan bantuan dari orang lain dengan kata lain kita hidup saling berdampingan dan juga hidup saling membutuhkan. Itulah pentingnya membangun relasi di masyarakat untuk mempermudah dalam menjalani kehidupan sehari-hari. Dapat dikatakan bahwa Pancasila dalam hal ini menjadi aspek penting untuk membangun karakter generasi bangsa (Sakti, 2017).

Nilai-nilai karakter yang diterapkan diambil dari nilai-nilai yang terdapat pada Pancasila. Pancasila memuat nilai-nilai atau karakter bangsa Indonesia yang tercermin dalam sila-sila Pancasila sebagai berikut:

a. Nilai-nilai ketuhanan yang maha esa yaitu mengenai kepercayaan dan ketaqwaan setiap orang pada tuhannya, kebebasan setiap orang dalam menganut agama sesuai dengan hati nurani, mencintai setiap makhluk hidup yang diciptakan oleh tuhan dan toleransi antar umat beragama lainnya.

b. Nilai-nilai Kemanusiaan yang Adil dan Beradab yaitu mengenai memiliki rasa empati dan simpati pada sesama, bersikap jujur, memandang setiap orang memiliki derajat yang sama, dan bersikap adil serta dapat memanusiakan manusia selaknya mereka sebagai seorang manusia.

c. Nilai-nilai Persatuan Indonesia yaitu mengenai rasa persatuan dan kesatuan, bagaimana kita mencintai bangsa dan negara Indonesia, memiliki jiwa nasioalisme dan patriotisme, mengesampingkan perbedaan dengan Bhineka Tunggal Ika.

d. Nilai-nilai Kerakyatan yang Dipimpin oleh Hikmat Kebijaksanaan Dalam Permusyawaratan Perwakilan yaitu mengenai kebebasan dalam menyampaikan pendapat, pelaksanaan musyawarah secara mufakat untuk mencapai tujuan bersama, serta hikmat kebijaksanaan.

e. Nilai-nilai Keadilan Sosial bagi Seluruh Rakyat Indonesia yaitu mengenai keadilan sosial yang diberikan sebagai seorang warga negara hal ini dapat berupa perlindungan dan jaminan atas hak asasi , upaya unntuk memberikan kesejahteraan bagi setiap warga negara, serta gotong royong untuk mewujudkan kerja sama dan rasa kekluargaan di masyarakat.

Semua itu bisa didapatkan pada mata pelajaran pendidikan Pancasila dan kewarganegaraan, saat ini nilai-nilai yang ada dalam Pancasila diberikan kemudian diterapkan pada seluruh mata pelajaran lain (Kurikulum 2013 revisi). Dengan hal ini tentu diharapkan akan terwujud penanaman nilai-nilai Pancasila disetiap pembelajaran yang dilakukan dalam lingkungan sekolah. Nilai karakter yang diterapkan tentu harus berdasarkan dengan kompetensi dasar yang dijadikan sebuah tujuan untuk dicapai dalam setiap pembelajaran. Nilai karakter ini tentu juga dapat dijadikan sebagai dasar pedoman dalam menyikapi isu yang berkembang di masyarakat jika dilihat dalam sudut pandang Pancasila. Sehingga dapat menyikapi isu yang berkembang tersebut sesuai dengan nilai-nilai yang ada dalam Pancasila, dengan hal ini maka tidak akan menimbulkan dampak buruk dalam cara menyikapi suatu isu. Dengan hal ini maka kita dapat mengikuti arus globalisasi namun juga tetap dapat mempertahankan nila-nilai Pancasila agar tetap mempertahankan budaya Indonesia. Penerapan nilaii-nilai Pancasila dapat dilakukan dengan cara menumbuhkan sikap patriotisme dan nasionalisme pada generasi penerus bangsa. Sikap nasionalisme dapat ditumbuhkan dengan mengikuti hari peringatan sumpah pemuda, upacara HUT RI, hari pahlawan dan peringatan hari besar lainnya. Peserta didik juga dapat memenuhi kewajiban mereka dengan belajar dengan sungguh-sungguh demi mewujudkan cita-cita bangsa Indonesia, memiliki jiwa cinta tanah air dengan mendukung produk 
lokal serta menggunakan barang tersebut untuk memajukan perekonomian Indonesia (Nono et al., 2019).

\section{Simpulan}

Berdasarkan hasil dari kajian yang di dapat dari berbagai sumber pustaka dapat diketahui bahwa Pancasila selain sebagai dasar negara juga memiliki peran yang besar dalam pembentukan karakter bagi generasi penerus bangsa. Berdasarkan dengan nilai-nilai yang ada pada Pancasila apabila diterapkan maka hal ini akan memiliki dampak yang besar dalam upaya membentuk karakter yang cerdas, kreatif, dan berakhlak mulia. Dalam dunia pendidikan nilai-nilai yang ada dalam Pancasila dapat di berikan melalui salah satu cara yaitu pembelajaran dengan pendidikan Pancasila. Upaya pembangunan karakter dapat dilakukan sejak usia dini guna terciptanya generasi penerus bangsa yang memiliki karakter sesuai dengan nilai-nilai Pancasila. Karena pada dasarnya Pancasila sebagai dasar awal pembentukan karakter pribadi yang cerdas, kreatif, dan berakhlak mulia. Nilai yang terkandung pada Pancasila yaitu nilai ketuhanan, kemanusiaan, persatuan, kerakyatan, dan keadilan. Pancasila memiliki sifat subjektif, yang berarti bahwa nilai yang terkandung dalam Pancasila berhubungan dengan yang menggunakan dan menerapkan nilai Pancasila, yaitu bangsa, negara Indonesia, dan tentu masyarakat.

\section{Referensi}

Adha, M. M., \& Susanto, E. (2020). Kekuatan Nilai-nilai Pancasila dalam Membangun Kepribadian Masyarakat Indonesia. Al-Adabiya: Jurnal Kebudayaan dan Keagamaan, 15(01), 121-138. https://doi.org/10.37680/adabiya.v15i01.319

Alzanaa, A. W., \& Harmawati, Y. (2021). Pendidikan Pancasila sebagai pendidikan multikultural. Citizenship Jurnal Pancasila dan Kewarganegaraan, 9(1), 51-57. http://ejournal.unipma.ac.id/index.php/citizenship/article/view/2370

Anggraini, D., Fathari, F., Anggara, J. W., \& Amin, M. D. A. Al. (2020). Pengamalan nilai-nilai Pancasila bagi generasi milenial. JISoP: Jurnal Inovasi Ilmu Sosial dan Politik, 2(1), 11-18. http://riset.unisma.ac.id/index.php/JISoP/article/view/4945/5419

Asmaroini, A. P. (2016). Implementasi nilai-nilai Pancasila bagi siswa di era globalisasi. Citizenship: Jurnal Pancasila dan Kewarganegaraan, 4(2), 440-450. http://ejournal.unipma.ac.id/index.php/citizenship/article/view/1077

Hanum, F. F. (2019). Pendidikan Pancasila bagi Generasi Milenial. In A. Wahyudi, R. Nababan, \& F. Rahman (Ed.), Seminar Nasional Reaktualisasi Konsep Kewarganegaraan Indonesia (hal. 72-81). Fakultas Ilmu Sosial Universitas Negeri Medan.

Mustoip, S., Japar, M., \& MS, Z. (2018). Implementasi Pendidikan Karakter. Jakad Publishing.

Nono, G. U., Hermuttaqien, B. P. F., \& Wadu, L. B. (2019). Hubungan Mata Pelajaran PPKn Terhadap Peningkatan Karakter Siswa. Jurnal Moral Kemasyarakatan, 3(2), 52-56. https://doi.org/10.21067/jmk.v3i2.2955

Nurgiansah, T. H. (2021). Pendidikan Pancasila Sebagai Upaya Membentuk Karakter Jujur T. Jurnal Pendidikan Kewarganegaraan Undiksha, 9(1), 33-41.

Resmana, M. T., \& Dewi, D. A. (2021). Pentingnya Pendidikan Pancasila untuk Merealisasikan Nilai-Nilai Pancasila dalam Kehidupan Bermasyarakat. Jurnal Pendidikan dan Kewirausahaan, 9(2), 473-485.

Sakti, B. P. (2017). Indikator Pengembangan Karakter Siswa Sekolah Dasar. Magistra, 29(101), 1-10. https://doi.org/10.31227/osf.io/pucw9

Sayektiningsih, Sumardjoko, B., \& Muhibin, A. (2017). Penanaman Nilai-Nilai Karakter dalam Pembelajaran Pendidikan Pancasila dan Kewarganegaraan di Madrasah Aliyah Muhammadiyah Klaten. Jurnal Manajemen Pendidikan, 12(2), 228-238. http://journals.ums.ac.id/index.php/jmp/article/download/5518/3593

Sulianti, A., Efendi, Y., \& Sa'diyah, H. (2020). Penerapan Nilai-Nilai Pancasila dalam Lembaga 
Silvia Oktaviana Lestari, Heri Kurnia. Peran Pendidikan Pancasila dalam Pembentukan Karakter

Pendidikan. Jurnal Pancasila dan Kewarganegaraan, 5(1), 54-65. https://doi.org/10.24269/jpk.v5.n1.2020.pp54-65

Wadu, L. B., Darma, I. P., \& Ladamay, I. (2019). Pengintegrasian Nilai Moral Melalui Pendidikan Pancasila dan Kewarganegaraan Di SMP. Jurnal Inspirasi Pendidikan, 9(1), 66-70. https://doi.org/10.21067/jip.v9i1.3067 